\title{
A study on awareness and disposal practices of unused and expired medicines by consumers
}

\author{
Bhavika D. ${ }^{1}$, Ayesha Vaseem ${ }^{1 *}$, Sunil Pal Singh C. $^{2}$
}

\begin{abstract}
${ }^{1}$ Department of Pharmacology, Government Medical College, Nalgonda, Telangana, India
${ }^{2}$ Department of Community Medicine, Kamineni Academy of Medical Sciences and Research Centre, Hyderabad, Telangana, India
\end{abstract}

Received: 22 December 2019

Revised: 15 February 2020

Accepted: 02 March 2020

*Correspondence:

Dr. Ayesha Vaseem,

Email: drayeshamazher@gmail.com

Copyright: (c) the author(s), publisher and licensee Medip Academy. This is an open-access article distributed under the terms of the Creative Commons Attribution Non-Commercial License, which permits unrestricted non-commercial use, distribution, and reproduction in any medium, provided the original work is properly cited.

\begin{abstract}
Background: Hazards to the environment due to improper drug disposal practices is an issue of concern. The prescription drugs, disposed into trash /sewage, consequently enter into surface waters and contaminate even drinking water. In view of the potential hazards posed due to improper storage and disposal of medicines, evaluation of the awareness of the consumers and educating them about proper disposal methods is required. The aim of present study was to evaluate the awareness and practice of drug disposal among the population.

Methods: A cross sectional, observational study was conducted at Rural Health Centre (RHTC) of Kamineni Academy of Medical Sciences and Research Centre with the patients visiting the RHTC as the study subjects. A predesigned questionnaire was used to evaluate the awareness and disposal practices of unused and expired medicines by the respondents.

Results: On analysis it was observed that $80(57 \%)$ of the respondents procure medicines from health care centre. A total of $97(69 \%)$ respondents possess unused/leftover medicines at home, 54 (39\%) of the respondents mentioned the reason to be due to self discontinuation. Among the class of drugs left unused antibiotics constituted $13 \%$, antipyretics $6 \%$, analgesics $6 \% .49 \%$ of the respondents dispose unused medicines in domestic trash, $24 \%$ flush down toilet/sink. A majority of $121(86 \%)$ opined that awareness must be made created.

Conclusions: In present study it was observed that many of the respondents possessed leftover medicines and were unaware of the hazards of improper disposal of medicines. Thus, there is a need for proper educational and regulatory interventions.
\end{abstract}

Keywords: Awareness, Disposal of medicines, Hazards of improper disposal, Leftover medicines, Unused medicines

\section{INTRODUCTION}

Medicines play an important role in prevention and treatment of various diseases and conditions. All over the world, it has been estimated that medicines are prescribed and dispensed inappropriately. ${ }^{1}$ In addition to that medicines are even stored and disposed inappropriately, paving way for hazards to the mankind and environment. Ecopharmacovigilance can be defined as science and activities concerning detection, assessment, understanding, and prevention of adverse effects or other problems related to the presence of pharmaceuticals in the environment, which affect human and other animal species. $^{2}$

In the first place excess or inappropriate prescription of drugs and lack of adherence to the prescribed course leads to chances of stocking up of left over drugs or improper 
storage of drugs. This leads to a threat of unintentional poisoning and self medication (without doctors orders). The left over or expired medicines are disposed inappropriately in the domestic trash and toilets/sinks, leading to a threat to the environment, all the living species including humans. The prescription drugs, through trash/sewage, consequently enter into surface waters and contaminate even drinking water.

Many pharmaceutical molecules have been investigated and detected in water bodies. These include antibiotics, analgesics/anti-inflammatory drugs, antidepressants, beta blockers. ${ }^{3}$ Thus, human beings and other living species are exposed directly or indirectly to drugs through the environment.

There are many instances of the consequences of drugs polluting the environment. Decline in the population of vultures feeding on livestock carcasses due to veterinary use of diclofenac, decrease in the number of frogs because of sterility due to exposure to traces of progestins and ethinyl estradiol in water and behavioural changes in fish due to pharmaceuticals in aquatic systems are some examples of impact of environmental contamination with drugs. ${ }^{4-6}$ An issue of utmost importance is antimicrobial resistance due to continuous exposure to antimicrobials through drinking water. ${ }^{7,8}$

Left over medicines disposed inappropriately, contribute to a significant extent to environmental contamination. ${ }^{8,9}$ The patients are given instructions regarding the use of medicines but are not educated regarding proper disposal of medicines. They resort to improper disposal practices.

Many studies were conducted assessing the knowledge and practices of the consumers related to proper drug disposal practices. ${ }^{10-13}$ All the studies addressed the need for educational and regulatory interventions for establishing proper drug disposal practices.

Educating the consumers regarding proper storage practices to avoid accidental ingestion by children, timely disposal of expired medicines and proper disposal methods is necessary. Ideally, implementing a medication take back program as in the U.S. helps in proper disposal of medicines and in reducing risk to environment and mankind. ${ }^{14}$ Steps are suggested for disposal of unused/expired pharmaceutical products by the Indian Pharmacopoeia commission in Appendix 4 of the National Formulary of India ( $4^{\text {th }}$ edition 2011). ${ }^{15}$ Inspite of the measures suggested the practice of improper disposal of unused medicines prevails.

In view of the potential hazards posed due to improper storage and disposal of medicines, evaluation of the awareness of the consumers and their practices related to drug disposal and educating them about proper disposal methods and planning out an effective drug take back program at community level is required.
Present study aims at evaluating the awareness and practice of drug disposal among the population and at evaluating the methods adopted by the consumers for drug disposal.

\section{METHODS}

\section{Study design}

A prospective cross sectional observational study was conducted during the period of May-June 2019 in the Rural Health centre (RHTC) of Kamineni Academy of Medical Sciences and Research Centre.

\section{Study population}

Patients attending the rural health centre (RHTC) and willing to participate were included in the study. The study population was explained about the purpose of the study and informed consent was taken.

\section{Data collection}

Data was collected by using a predesigned, pretested questionnaire. The first part of the questionnaire included demographic details of the respondents like age, sex, educational status, employment status and residential area. The other questions were addressed towards the practices of the respondents such as possession of unused/leftover medicines at home (response as yes/no), if yes the class of medicines stored, reason for possession of unused medicines, storage practices and method of disposal of unused/ leftover medicines. The questionnaire included some questions pertaining to the awareness of the respondents regarding the hazards of improper disposal practices, and proper method of drug disposal and the response was taken as yes/no. If the response was yes then they were asked 'what are the hazards?' and 'what are the proper methods of disposal?' In the later part of the questionnaire some questions were addressed towards the perception of the respondents like "Do you think people must be made aware of the hazards of improper disposal of medicines?", "Best possible way to stop hazards of unused medicines on human health, environment and animal life?" and "Methods for educating people regarding safe disposal of drugs".

\section{Data analysis}

Data was collected and entered in M.S Excel. Results were expressed (as percentages) in Tabular forms/graphs.

\section{RESULTS}

The present study was conducted in Rural Health centre of Kamineni Academy of Medical sciences and research centre, LB Nagar. A total of 140 respondents participated in the study. Among the respondents there were 55(39\%) females and $85(61 \%)$ males shown in Table 1 . The demographic variables like age distribution, educational 
status, Occupation and residential area of the respondents is presented in.

Table 1: Table representing demographic variables.

\begin{tabular}{|ll|}
\hline Demographic variables & No. of respondents (\%) \\
\hline Age group (in years) & \\
\hline 18 & $1(0.7)$ \\
\hline $22-25$ & $14(10)$ \\
\hline $26-30$ & $18(13)$ \\
\hline $31-35$ & $22(16)$ \\
\hline $36-40$ & $16(11)$ \\
\hline $41-45$ & $18(13)$ \\
\hline $46-50$ & $15(11)$ \\
\hline$>50$ & $36(26)$ \\
\hline Sex & \\
\hline Female & $55(39)$ \\
\hline Male & $85(61)$ \\
\hline Educational status & \\
\hline Illiterate & $22(16)$ \\
\hline Primary school & $40(29)$ \\
\hline Secondary school & $41(29)$ \\
\hline Intermediate & $21(15)$ \\
\hline Graduation & $13(9)$ \\
\hline Postgraduation & $3(2)$ \\
\hline Occupation & $37(26)$ \\
\hline Unemployed & $29(21)$ \\
\hline Unskilled & $48(34)$ \\
\hline Semiskilled & $17(12)$ \\
\hline Skilled & $6(4)$ \\
\hline Semiprofessional & $3(2)$ \\
\hline Professional & $79(56)$ \\
\hline Residential area & $61(44)$ \\
\hline Rural & \\
\hline Urban & \\
\hline
\end{tabular}

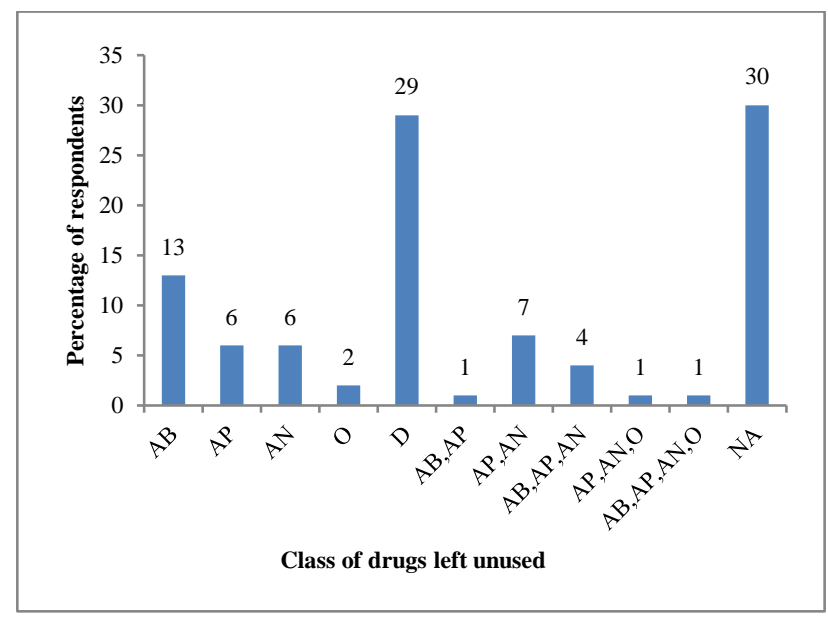

Figure 1: Chart showing the class of drugs left unused and stored at home.

AB-Antibiotics; AP-Antipyretics; AN-Analgesics; O-Others; DDon't know; NA-Not attempted
On analysis of the practices of the respondents it was observed that $80(57 \%)$ of the respondents procure medicines from health care centre, $26(19 \%)$ from medical stores with doctors prescription, 6 (4\%) from Over the counter purchase and $4(3 \%)$ from medical store without prescription (Table 3).

It was observed that a total of $97(69 \%)$ of the respondents possess unused/leftover medicines at home (Table 2). On analysis of the reasons for presence of unused medicines it was observed that $54(39 \%)$ of the respondents mentioned the reason to be due to self-discontinuation, $9(6 \%)$ had purchased more than needed for future use, $4 \%$ due to change in prescription, $4 \%$ possessed medicines which have crossed expiry date and $3 \%$ due to discontinuation as a consequence of adverse drug reaction (Table 4). Among the class of drugs left unused, antibiotics constituted $13 \%$, antipyretics $6 \%$, analgesics $6 \%$ and $29 \%$ of the respondents didn't know the class of drugs which were left over/unused (Figure 1).

Table 2: Awareness and practices of respondents towards drug disposal practices and hazards of improper drug disposal.

\begin{tabular}{|c|c|c|}
\hline $\begin{array}{l}\text { Questions related to } \\
\text { awareness and practices }\end{array}$ & Yes (\%) & No (\%) \\
\hline $\begin{array}{l}\text { Do you have any unused } \\
\text { medicines at home }\end{array}$ & 97 (69) & $43(31)$ \\
\hline $\begin{array}{l}\text { Do you store medicines at } \\
\text { sites accessible to children }\end{array}$ & $71(51)$ & 69 (49) \\
\hline $\begin{array}{l}\text { Are you aware of hazards } \\
\text { of improper disposal of } \\
\text { medicines }\end{array}$ & $66(47)$ & $74(53)$ \\
\hline $\begin{array}{l}\text { Are you aware of safe } \\
\text { methods of drug disposal }\end{array}$ & $72(51)$ & 68 (49) \\
\hline $\begin{array}{l}\text { Did you receive instructions } \\
\text { for safe disposal of medicines }\end{array}$ & $81(58)$ & $59(42)$ \\
\hline $\begin{array}{l}\text { Do you think people must be } \\
\text { made aware of the hazards }\end{array}$ & $121(86)$ & 19 (14) \\
\hline
\end{tabular}

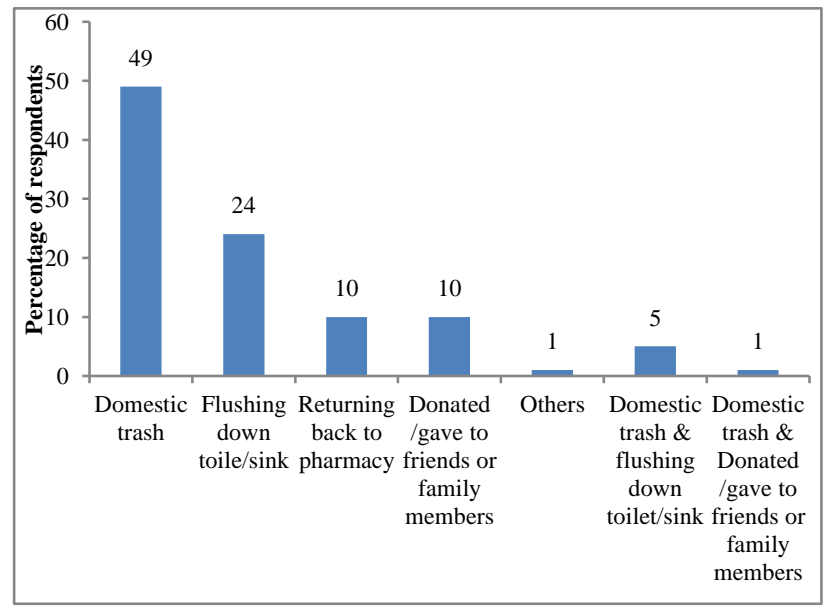

Figure 2: Methods of disposal of unused medicines adopted by the respondents. 
It was observed that $71(51 \%)$ respondents stored medicines at sites accessible to children (Table 2). On evaluating the disposal practices it was observed that $49 \%$ of the respondents dispose unused medicines in domestic trash, $24 \%$ flush down toilet/sink, $10 \%$ return back to pharmacy and $10 \%$ of the respondents give the unused medicine to family members/friends (Figure 2).

On evaluating the awareness of respondents towards the hazards of improper disposal of medicines, 74 (53\%) respondents were not aware of the hazards (Table 2). Among the respondents $72(51 \%)$ were aware of safe methods of drug disposal. When asked about the safe methods $54(39 \%)$ respondents return the leftover medicine to health care centre, while $16(11 \%)$ return to pharmacy (Table 5).

Table 3: Sources of medicines procured by the respondents.

\begin{tabular}{|l|l|}
\hline Source of medicines & $\begin{array}{l}\text { Number of } \\
\text { respondents (\%) }\end{array}$ \\
\hline Over the counter & $6(4)$ \\
\hline Health care centre & $80(57)$ \\
\hline $\begin{array}{l}\text { Medical stores with doctor's } \\
\text { prescription }\end{array}$ & $26(19)$ \\
$\begin{array}{l}\text { Medical stores without } \\
\text { prescription }\end{array}$ & $4(3)$ \\
\hline $\begin{array}{l}\text { Other sources } \\
\text { More than one of the above } \\
\text { response }\end{array}$ & $1(1)$ \\
\hline
\end{tabular}

Table 4: Reasons for presence of unused medicines at home.

\begin{tabular}{|l|l|}
\hline $\begin{array}{l}\text { Reason for presence of unused } \\
\text { medicines at home }\end{array}$ & $\begin{array}{l}\text { Number of } \\
\text { respondents }(\%)\end{array}$ \\
\hline Change in the prescription & $5(4)$ \\
\hline Self discontinuation & $54(39)$ \\
\hline Dispensed more than needed & $6(4)$ \\
\hline $\begin{array}{l}\text { Medicine crossed expiry date } \\
\text { Left over from previous OTC } \\
\text { purchase }\end{array}$ & $5(4)$ \\
\hline $\begin{array}{l}\text { Purchased more than needed for } \\
\text { future use }\end{array}$ & $9(6)$ \\
\hline $\begin{array}{l}\text { Discontinued due to adverse } \\
\text { drug reaction }\end{array}$ & $4(3)$ \\
\hline $\begin{array}{l}\text { More than one of the above } \\
\text { reasons }\end{array}$ & $14(10)$ \\
\hline Not attemped & $42(30)$ \\
\hline
\end{tabular}

A total of $81(58 \%)$ participants responded that they received instructions for safe disposal of medicines. A majority of $121(86 \%)$ respondents were of the opinion that people must be made aware of the hazards (Table 2).

Among the respondents 60(43\%) were of the opinion that creating awareness among the people is the best way to stop hazards, $42(30 \%)$ respondents were of the opinion that conducting take back program is the best way and 19(14\%) of respondents were of the opinion that stringent rules on purchase and dispensing of medicines is the best way (Figure 3).

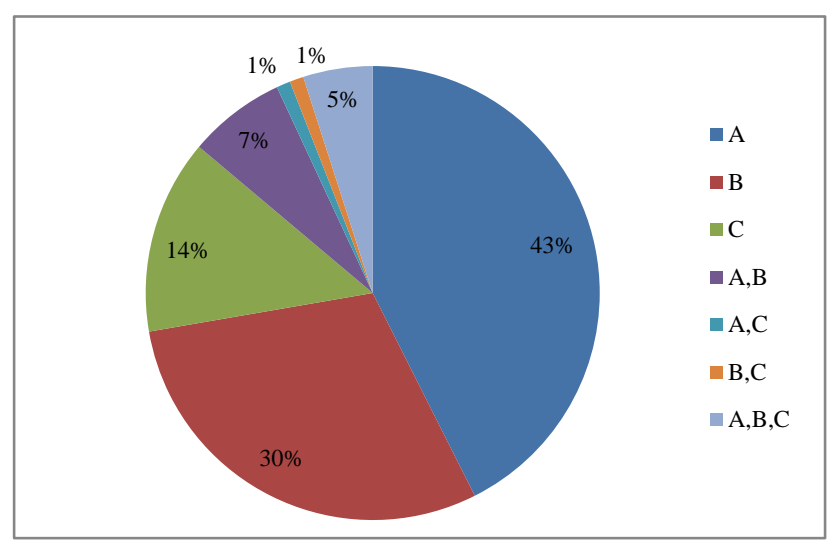

Figure 3: Chart showing the responses regarding best way to stop hazards of improper drug disposal.

A- Creating awareness among the people; B- Conducting drug take back programs; C- Stringent rules on purchase and dispensing of medicines.

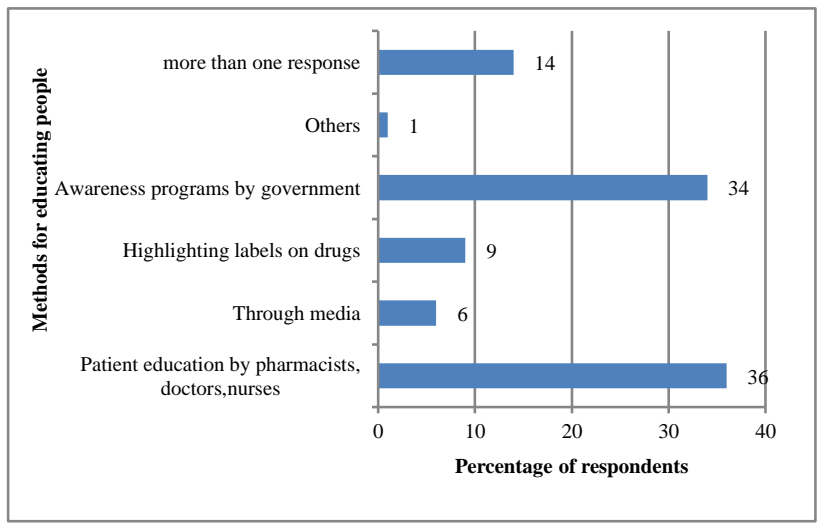

Figure 4: Methods for educating people regarding safe disposal of drugs.

On evaluating the methods for educating people regarding safe disposal of drugs, the opinion of $36 \%$ of respondents was education by pharmacists, doctors, nurses, followed by $34 \%$ opting for awareness programs by government, followed by $9 \%$ opting for highlighting labels on drugs (Figure 4).

Table 5: Methods of safe disposal of drugs according to the respondents.

\begin{tabular}{|l|l|}
\hline $\begin{array}{l}\text { Methods of safe disposal of } \\
\text { drugs }\end{array}$ & $\begin{array}{l}\text { Number of } \\
\text { respondents }(\%)\end{array}$ \\
\hline Return to pharmacy & $16(11)$ \\
\hline Return to health care centre & $54(39)$ \\
\hline $\begin{array}{l}\text { Return to pharmacy and return } \\
\text { to health care centre }\end{array}$ & $2(1)$ \\
\hline Not attempted & $68(49)$ \\
\hline
\end{tabular}




\section{DISCUSSION}

In present study majority of the respondents were males $(61 \%)$ and majority of them were educated upto primary school, and secondary school level. A majority of $57 \%$ of the respondents had procured medicines from health care centre, while only $3 \%$ of the respondents had procured medicines from medical stores without prescription. In a study by Sonowal et al $60.5 \%$ of the respondents procured medicines from pharmacy with doctor's prescription but a greater number of respondents (20\%) had procured medicines without prescription when compared to our study. ${ }^{10}$

On evaluating the practices of respondents it was observed that $69 \%$ of the respondents had leftover/unused medicine at home. Similar findings were there in the study by Sonowal S et al. ${ }^{10}$ In a study by Bashaar $\mathrm{M}$ et at $95.3 \%$ of the respondents had unused medicines at home. ${ }^{12}$ Majority $(29 \%)$ of the respondents didn't know the class of medicines left over with them. Among the class of drugs left unused, antibiotics constituted a significant proportion. The most common reason for presence of leftover/unused medicines was self-discontinuation $39 \%$ of the respondents). A significant number $(51 \%)$ of respondents store medicines at sites accessible to children. On evaluation of disposal practices it was observed that majority $(49 \%)$ of respondents discarded unused medicines in domestic trash, followed by $124 \%$ of respondents flushing down sink/ toilet, while only $10 \%$ of them return back the unused drugs to pharmacy. In other studies also the majority of the respondents had disposed the leftover medicines into domestic trash. ${ }^{10-13}$

On evaluating the awareness of the respondents it was noted that $53 \%$ of the respondents were unaware of the hazards of improper disposal of medicines. This could be the reason behind the practices followed for disposal of unused medicine by the respondents and points towards the need for creating awareness among the people regarding the hazards of improper drug disposal practices and proper methods of drug disposal. It was observed that $51 \%$ of respondents were aware of safe methods of drug disposal and despite the awareness of proper methods of drug disposal only $10 \%$ of the respondents returned unused medicines back to the pharmacy.

On questioning about the instructions received for safe disposal of medicines $58 \%$ had accepted that they received instructions.

On evaluating the opinion of the people regarding the issue and the methods to tackle the problem, it was observed that $86 \%$ of the respondents were of the opinion that awareness should be created regarding the hazards and $36 \%$ of the respondents were of opinion that patient must be educated by pharmacists, doctors and nurses, and $34 \%$ opined that awareness programs by government are the methods for educating people regarding safe disposal of drugs. Similar findings were observed in study by Sonowal et al. ${ }^{10}$
Methods for disposal of pharmaceuticals and personal care products (PPCP) are mentioned in the National Formulary of India, which suggests that the expired or unused medicines should be returned by the chemists, druggists, pharmacies, clinics, hospitals to the manufacturers for proper disposal. ${ }^{15}$ Despite this, there are incidences of pharmaceutical drugs and their metabolites in aquatic and terrestrial ecosystems. The compounds enter the ecosystem due to discharge of pharmaceutical effluents which are not treated and improper disposal of expired or unused drugs. ${ }^{16}$ The pharmaceutical residues may also enter the ecosystem through excretion of animals and human beings, sewage treatment plants. Thus there is a need to implement required strategies for proper management of disposal of medicines. There is a need to conduct drug take back programs and frame guidelines for managing proper disposal of unused/leftover medicines. There is a need to conduct awareness programs and sensitize all stakeholders involved in use of and disposal of medicines.

\section{CONCLUSION}

In present study on evaluation it was observed that many of the respondents were possessing unused/leftover medicines and were not aware of the hazards of improper disposal of medicines and were not aware of proper methods of drug disposal. Though a significant proportion of the respondents were aware of the hazards, the disposal practices followed by the respondents are not satisfactory. Thus, there is a need for proper educational interventions in the form of awareness programs and regulatory interventions, with the government, media, pharmacists, health professionals and the consumers as the main stakeholders.

\section{ACKNOWLEDGEMENTS}

The authors would like to acknowledge Dr. K. Santosh Kumar, Professor and Head, Department of Pharmacology, KAMSRC, Hyderabad, and Dr. P. Narsimha Reddy, Professor and Head, Department of Community Medicine, KAMSRC, Hyderabad for their valuable support and guidance, and Dr. Gautami, Lady Medical officer, the house surgeons and the staff posted in the Rural Health Centre for their help without which the study would not have been possible.

Funding: No funding sources

Conflict of interest: None declared

Ethical approval: The study was approved by the Institutional Ethics Committee

\section{REFERENCES}

1. The World Medicines Situation: Chapter 8. Rational use of medicines. Available at: apps.who.int/ medicinedocs/en/d/Js6160e/10.html. Accessed 5 April 2019.

2. Silva LJG, Lino CM, Meisel L, Barcelo D, Pena A. Ecopharmacovigilance. In: Barcelo D, ed. The 
Handbook of Environmental Chemistry. Germany: Springer-Verlag Berlin and Heidelberg GmbH \& Co. KG; 2012:213-242.

3. Atkinson R. Pharmaceuticals in the Environment. Distribution of Pharmaceutical Residues in the environment. In: Hester RE, Harrison RM, eds. Issues in Environmental Science and Technology; 2016;41:36.

4. Taggart MA, Senacha KR, Green RE, Jhala YV, Raghavan B, Rahmani AR, et al. Diclofenac residues in carcasses of domestic ungulates available to vultures in India. Environ Int. 2007;33(6):759-65.

5. Säfholm M, Ribbenstedt A, Fick J, Berg C. Risks of hormonally active pharmaceuticals to amphibians: a growing concern regarding progestagens. Philos Transact Royal Soc Lond B Biol Sci. 2014;369(1656):20130577.

6. Brodin T, Piovano S, Fick J, Klaminder J, Heynen M, Jonsson M. Ecological effects of pharmaceuticals in aquatic systems- impacts through behavioural alterations. Philos Transact Royal Soc B Biol Sci. 2014;369(1656):20130580.

7. Ding C, He J. Effect of antibiotics in the environment on microbial populations. Applied Microbiol Biotech. 2010;87(3):925-41.

8. Medhi B, Sewal RK. Ecopharmacovigilance: An issue urgently to be addressed. Indian J Pharmacol. 2012;44(5):547-9.

9. Daughton CG, Ruhoy IS. The afterlife of drugs and the role of pharmecovigilance. Drug Safety. 2008;31(12):1069-82.
10. Sonowal S, Desai C, Kapadia JD, Desai MK. A survey of knowledge, attitude, and practice of consumers at a tertiary care hospital regarding the disposal of unused medicines. J Basic Clin Phar. 2016;8(1):4-7.

11. AlAzmi A, AlHamdan H, Abualezz R, Bahadig F, Abonofal N, Osman M. Patients' knowledge and attitude toward the disposal of medications. J Pharm. 2017;2017:1-9.

12. Bashaar M, Thawani V, Hassali MA, Saleem F. Disposal practices of unused and expired pharmaceuticals among general public in Kabul. BMC Public Health. 2017;17(1):45.

13. Lim MT. Disposal Practices of Unused and Unwanted Medications among Patients in a Tertiary Hospital. Educa Med J. 2016;8(3):49-59.

14. Patil S, Patil SK. Critical eye towards storage and disposal of prescribed medicine. Global J Med Public Health. 2013;2(6):1-5.

15. National Formulary of India: Disposal of unused/expired pharmaceutical products (Appendix 4). 4th Edition. Indian Pharmacopoeia commission; 2011.

16. Chander V, Sharma B, Negi V, Aswal RS, Singh P, Singh R, et al. Pharmaceutical compounds in drinking water. J Xenobiotics. 2016;6(1):5774.

Cite this article as: Bhavika D, Vaseem A, Singh SPC. A study on awareness and disposal practices of unused and expired medicines by consumers. Int $\mathbf{J}$ Basic Clin Pharmacol 2020;9:556-61. 